\title{
Ligandless Cloud Point Extraction for Trace Nickel Determination in Water Samples by Flame Atomic Absorption Spectrometry
}

\author{
Hosssein Abdolmohammad-Zadeh* and Elnaz Ebrahimzadeh \\ Department of Chemistry, Faculty of Sciences, Azarbaijan University of Tarbiat Moallem, \\ P.O. Box 53714-161 Tabriz, Iran
}

\begin{abstract}
Para a preconcentração de quantidades traço de níquel foi desenvolvida uma metodologia muito simples a partir da extração do ponto nuvem (CPE) e com a ausência de ligantes-quelantes como uma etapa prévia para a determinação de Ni por espectrometria de absorção atômica com chama (FAAS). O método é baseado na extração de Ni em pH 10 usando-se o surfactante iônico mono-p-nonilfenileter polietilenoglicol (PONPE 7.5) sem adição de nenhum agente quelante. As variáveis que afetam a eficiência da extração foram investigadas e otimizadas. O limite de deteção (LOD) e o limite de quantificação (LOQ) para a preconcentração de $50 \mathrm{~mL}$ de uma solução aquosa de $\mathrm{Ni}^{2+}$ foram $0,5 \mu \mathrm{g} \mathrm{L} \mathrm{L}^{-1}$ e $1,6 \mu \mathrm{g} \mathrm{L} \mathrm{L}^{-1}$, respectivamente. Os desvios padrão relativos (RSD) para seis determinações em replicatas de soluções contendo 50 e $80 \mu \mathrm{L} \mathrm{L}^{-1} \mathrm{de} \mathrm{Ni}^{2+}$ foram 2,67\% e $1,97 \%$, respectivamente. A curva analítica de calibração, com a preconcentração, mostrou-se linear no intervalo avaliado e com um coeficiente de correlação $r=0.9941$. O método proposto foi validado com análise do material de referência certificado de água NIST SRM 1643e e o resultado encontra-se de acordo com o valor certificado. O método foi aplicado com sucesso à determinação de quantidades traço de íons Ni em amostras de água.
\end{abstract}

A very simple and ligandless cloud point extraction (CPE) methodology has been developed for the preconcentration of trace amounts of nickel as a prior step to its determination by flame atomic absorption spectrometry (FAAS). The method is based on the extraction of nickel at $\mathrm{pH} 10$ by using non-ionic surfactant polyethyleneglycol mono- $p$-nonylphenylether (PONPE 7.5) without adding any chelating agent. Several variables affecting the extraction efficiency were investigated and optimized. The limit of detection (LOD) and limit of quantification (LOQ) values of nickel for the preconcentration of $50 \mathrm{~mL}$ of aqueous solution were $0.5 \mu \mathrm{g} \mathrm{L}^{-1}$ and $1.6 \mu \mathrm{g} \mathrm{L}{ }^{-1}$, respectively. The relative standard deviation (RSD) for six replicate determinations at 50 and $80 \mu \mathrm{g} \mathrm{L} \mathrm{L}^{-1}$ of $\mathrm{Ni}$ were $2.67 \%$ and $1.97 \%$, respectively. The calibration graph using the preconcentration system for nickel was linear with a correlation coefficient $r=0.9941$. To validate the proposed method a standard reference material NIST SRM 1643e (trace elements in water) was analyzed and the result was in good agreement with the certified value. The proposed method was successfully applied to determination of trace amounts of nickel in water samples.

Keywords: nickel, ligand-less cloud point extraction, PONPE 7.5, FAAS, water samples

\section{Introduction}

Nickel is an essential metal to plants and some animals, being a component of the enzyme urease and of five other important enzymes. ${ }^{1}$ However, even at low concentration, it may have a general toxic effect on human organism, causing nosopharynx, lung disease, malignant tumors and dermatological problems. ${ }^{2}$ Nickel enters waters from dissolution of rocks and soils, biological cycles, atmospheric fallout, especially from

*e-mail: h.abdol@azaruniv.edu,h_abdol@yahoo.com industrial processes and waste disposal. The World Health Organization (WHO) has proposed a guideline value of $20 \mu \mathrm{g} \mathrm{L}^{-1}$ for the maximum permissible concentration of nickel in drinking water. ${ }^{3}$ Therefore, it is essential to establish simple, rapid and sensitive methods for monitoring of nickel at trace levels in environmental samples.

Several analytical techniques such as UV-Vis spectrophotometry, ${ }^{4,5}$ spectrofluorimetry, ${ }^{6}$ atomic fluorescence spectrometry, ${ }^{7,8}$ laser-induced breakdown spectroscopy, ${ }^{9}$ X-ray fluorescence (XRF) spectrometry, ${ }^{10}$ flame atomic absorption spectrometry (FAAS), ${ }^{11-13}$ 
electrothermal atomic absorption spectrometry (ET-AAS), ${ }^{14-16}$ inductively coupled plasma optical emission spectrometry (ICP-OES), ${ }^{17-19}$ inductively coupled plasma mass spectrometry (ICP-MS $)^{20,21}$ and electroanalytical techniques ${ }^{22-24}$ have been reported for the determination of nickel in different real samples. However, the direct determination of trace levels of nickel in natural waters is limited and difficult when its concentration is too low to be determined directly and/or interference due to the matrix cannot be eliminated. ${ }^{25}$ Therefore, a preliminary separation and preconcentration prior to determination could be a good choice.

Several methods have been proposed for separation and preconcentration of trace amount of nickel including liquid-liquid extraction (LLE), ${ }^{26-28}$ solid phase extraction (SPE), ${ }^{29-32}$ cloud point extraction $(\mathrm{CPE})^{33-36}$ and liquid phase microextraction (LPME). ${ }^{37-39}$

Preconcentration methods involving cloud point extraction have attracted considerable attention because the procedures are fast, simple and efficient, avoid the use of large quantities of toxic organic solvents and promote high enrichment factors. The phenomenon of cloud point is based on the fact that aqueous solutions of non-ionic surfactants become cloudy in a narrow range of temperature. Above this temperature, the solution is separated into two distinct phases: a phase with small volume and rich in surfactant, and a phase that is poor in surfactant. ${ }^{40}$ The principle, advantages and limitation of CPE have been summarized in several reviews. ${ }^{41,42}$

There are two kinds of CPE procedures which may be used for separation and preconcentration of metal ions. In first procedure, metal ions could be extracted into the surfactant rich phase after complex formation with a suitable ligand. Other method is based on direct application of CPE procedure without any ligand. According to our literature study, ligandless procedure has been applied to nickel preconcentration using Tween 80 as surfactant prior to its determination by FAAS. ${ }^{43}$ However, this method is time-consuming and takes more than $1 \mathrm{~h}$. In the present work, PONPE 7.5 was applied as both chelating agent and extractant to preconcentration of nickel. The proposed method was successfully applied to determination of trace amounts of nickel in water samples.

\section{Experimental}

\section{Apparatus}

A Varian model SpectrAA 220 (Mulgrave, Victoria, Australia) flame atomic absorption spectrometer with flame atomizer, equipped with deuterium lamp background correction and a nickel hollow cathode lamp as the radiation source were used. The wavelength, lamp current and spectral resolution used, were $232 \mathrm{~nm}, 5 \mathrm{~mA}$ and $0.2 \mathrm{~nm}$, respectively. The nebulizing flow rate, integration time, acetylene and air flow rates were $6.0 \mathrm{~mL} \mathrm{~min}{ }^{-1}, 0.1 \mathrm{~s}, 1.5$, and $3.5 \mathrm{~L} \mathrm{~min}^{-1}$, respectively. A centrifuge (Beckman GS-6, USA) was used to accelerate phase separation process. The $\mathrm{pH}$ values were measured with a Metrohm $\mathrm{pH}$ meter (model 827, Switzerland), equipped with glass combined electrode. A thermostated water bath (Julabo) model GMBH D-77960 was obtained from Germany. An electronic analytical balance (Mettler Toledo, PB303, Switzerland) was used for weighting the solid materials.

\section{Standard solutions and reagents}

All chemicals used were of analytical-reagent grade and all solutions were prepared with doubly distilled deionized water (Shahid Ghazi Co, Tabriz, Iran). Stock solutions of nickel and those used for the interference study $\left(1000 \mu \mathrm{g} \mathrm{m}^{-1}\right)$ were prepared by dissolving appropriate amounts of their corresponding salts in deionized water. The working standard solutions were prepared daily by stepwise diluting the stock standard solution with deionized water.

As it is not possible to obtain a real aqueous solution of the surfactant PONPE 7.5 (polyethyleneglycol monop-nonylphenylether, Tokyo Kasei Industries, Chuo-Ku, Tokyo, Japan) since the cloud point of its micellar solution is markedly below room temperature, it was experimentally convenient to prepare a working solution as follows: $1.5 \mathrm{~mL}$ surfactant PONPE 7.5 and $20 \mathrm{~mL}$ distilled ethanol (Merck), were mixed and made up to $50 \mathrm{~mL}$ with deionized water. ${ }^{44}$

A stock buffer solution $\left(0.1 \mathrm{~mol} \mathrm{~L}^{-1}\right)$ was prepared by dissolving appropriate amounts of sodium carbonate (Merck) in deionized water and adjusting to $\mathrm{pH} 10$ by adding diluted $\mathrm{HNO}_{3}$ (Merck) solution. $\mathrm{A} 2 \mathrm{~mol} \mathrm{~L}{ }^{-1} \mathrm{NaNO}_{3}$ solution was used for ionic strength study. The pipettes and vessels used for trace analysis were kept in 15\% (v/v) nitric acid at least overnight and subsequently washed three times with deionized water.

\section{General procedure}

For the cloud point extraction experiments, an aliquot of $50 \mathrm{~mL}$ of a solution containing $\mathrm{Ni}^{2+}$ in the range of $2-100 \mu \mathrm{g} \mathrm{L}{ }^{-1}$, carbonated buffer solution $\left(5 \times 10^{-3} \mathrm{~mol} \mathrm{~L}^{-1}\right.$, $\mathrm{pH} 10)$ and $0.12 \%(\mathrm{v} / \mathrm{v})$ PONPE 7.5 were placed in a centrifuge tube. The mixture was diluted to $50 \mathrm{~mL}$ with deionized water. The resultant solution immediately was turbid at room temperature without heating. Phase separation was accelerated by centrifuging the tubes 
at $4000 \mathrm{rpm}$ for $10 \mathrm{~min}$. The aqueous phase was then separated completely by a $10 \mathrm{~mL}$ syringe centered in the tube without cooling in an ice bath. Afterward, any residue of water was removed from the surfactant rich phase by evaporation in water bath. The total volumes of surfactant rich phase obtained at room temperature phase separation before and after heating were 250 and $100 \mu \mathrm{L}$, respectively. Finally, the residual was made up to $500 \mu \mathrm{L}$ by adding the $0.1 \mathrm{~mol} \mathrm{~L}^{-1} \mathrm{HNO}_{3}$ in methanol to decrease the viscosity, and the resultant solution was introduced into the flame by conventional aspiration. A reagent blank was prepared using a similar procedure but without nickel. The optimized conditions are listed in Table 1. In the impact parameters optimization procedure, the limits marked on the figures were obtained from three experiments that were repeated under the same conditions.

Table 1. Instrumental and experimental conditions for nickel determination

\begin{tabular}{lc}
\hline FAAS conditions & \\
\hline Wavelength $(\mathrm{nm})$ & 232 \\
Lamp current $(\mathrm{mA})$ & 5 \\
Spectral bandpass $(\mathrm{nm})$ & 0.2 \\
Acetylene flow rate $\left(\mathrm{L} \mathrm{min}^{-1}\right)$ & 1.5 \\
Air flow rate $\left(\mathrm{L} \mathrm{min}^{-1}\right)$ & 3.5 \\
Nebulizing flow rate $\left(\mathrm{mL} \mathrm{min}^{-1}\right)$ & 6.0 \\
Integration time $(\mathrm{s})$ & 0.1 \\
\hline Cloud point extraction conditions & \\
\hline Working pH & 10 \\
Ni ${ }^{2+}$ concentration $\left(\mu \mathrm{g} \mathrm{L} \mathrm{L}^{-1}\right)$ & 50.0 \\
Surfactant concentration $(\mathrm{v} / \mathrm{v})$ & $0.12 \%$ \\
Buffer concentration $(\mathrm{mol} \mathrm{L}$ & -1 ) \\
Centrifugation time $(\mathrm{min})$ & $5 \times 10^{-3}$ \\
\hline
\end{tabular}

\section{Sample preparation}

Water samples including tap water, rain water, mineral water, spring water, river water and waste water were collected from local sources. After sampling, they were filtered through Rund filter paper (blue band, no. 300210) to remove suspended particulate matter. Aliquots of $50.0 \mathrm{~mL}$ from each sample solution were used for the analysis.

\section{Results and Discussion}

\section{Selection of surfactant}

To select an appropriate surfactant for ligandless CPE of nickel, several non ionic surfactant such as Triton X-100, Triton X-114 and PONPE 7.5 were tested. Among these, PONPE 7.5 showed the best extraction efficiency. PONPE 7.5 is a polyoxyethylene non-ionic surfactant with molecular formula of $\mathrm{HO}\left(\mathrm{CH}_{2} \mathrm{CH}_{2} \mathrm{O}\right)_{7.5} \mathrm{C}_{6} \mathrm{H}_{4} \mathrm{C}_{9} \mathrm{H}_{19}$ and critical micellar concentration (CMC) of $0.085 \mathrm{mmol} \mathrm{L}^{-1}$. The cloud point temperature (CPT) of PONPE 7.5 depends on its concentration and for a $5 \%(\mathrm{~m} / \mathrm{m})$ solution has been reported to be $5{ }^{\circ} \mathrm{C} .{ }^{45}$ This temperature can be modified by the presence of alcohols, salts, alkalis, acids, polymers and other surfactants. As an example, in the presence of $40 \%$ (v/v) ethanol, CPT of the studied micellar system for a 3\% (v/v) of PONPE 7.5 solution was higher than $40{ }^{\circ} \mathrm{C}$. However, it was observed that the CPT of PONPE 7.5 decreased to about $20^{\circ} \mathrm{C}$ when the concentration of ethanol was decreased to $2 \%(\mathrm{v} / \mathrm{v})$, working at a surfactant concentration of $0.2 \%(\mathrm{v} / \mathrm{v})$.

Although regular solution theory predicts that partition constants of the metal chelates will be almost independent of the metal ion nature, they vary with the kind of extracted metal in the case of CPE with PONPE 7.5. The mechanism in the variation of the partition constants could be explained in terms of the presence of microscopically ordered structures in the surfactant phase, such as those in liquid crystals, which can distinguish slight differences in molecular size, shape and structural factors. ${ }^{46}$ In our previous works, we conclude that cadmium, ${ }^{44}$ silver, ${ }^{47}$ and gold ${ }^{48}$ were coordinated to ethylene oxide groups of PONPE 7.5 at different $\mathrm{pH}$ in the form of $[\mathrm{Cd}(\mathrm{OH})]^{+}, \mathrm{Ag}^{+}$and $\mathrm{HAuCl}_{4}$, respectively. In the present work, PONPE 7.5 may form a cationic complex with $[\mathrm{Ni}(\mathrm{OH})]^{+}$at $\mathrm{pH} 9.4$ through their polyoxyethylene groups and thereby can be extracted in surfactant-rich phase. The cloud point of the studied system is near room temperature $\left(20^{\circ} \mathrm{C}\right)$; therefore, the phase separation can be made without heating the micellar solutions. Hence, the micellar solution is immediately turbid at room temperature $\left(25^{\circ} \mathrm{C}\right)$. Moreover, in this system, after centrifugal settling, the two phases are easily separated without cooling in an ice bath. Therefore, PONPE 7.5 was chosen as a micellar system for experiments.

\section{Effect of $p H$}

The effect of $\mathrm{pH}$ on the cloud point extraction of nickel was investigated within the range of $\mathrm{pH}$ 5-12 using diluted $\mathrm{HCl}$ and/or $\mathrm{NaOH}$. The results are illustrated in Figure 1. As can be seen, the quantitative extraction begins at $\mathrm{pH}$ 9.5, being constant until $\mathrm{pH}$ 11. Since the $\mathrm{pKa}$ value for the hydrolysis of nickel is about $9.4{ }^{49}$ therefore, in the $\mathrm{pH}$ range of 9.5-11 the nickel ions exist mainly in the form of $[\mathrm{Ni}(\mathrm{OH})]^{+}$. The lower extraction efficiency in acidic media may be due to the fact that $\mathrm{H}^{+}$ions can also bind to polyoxyethylene groups of surfactant. ${ }^{47}$ As a result, $\mathrm{pH} 10$ was selected as the working value in subsequent experiments. 


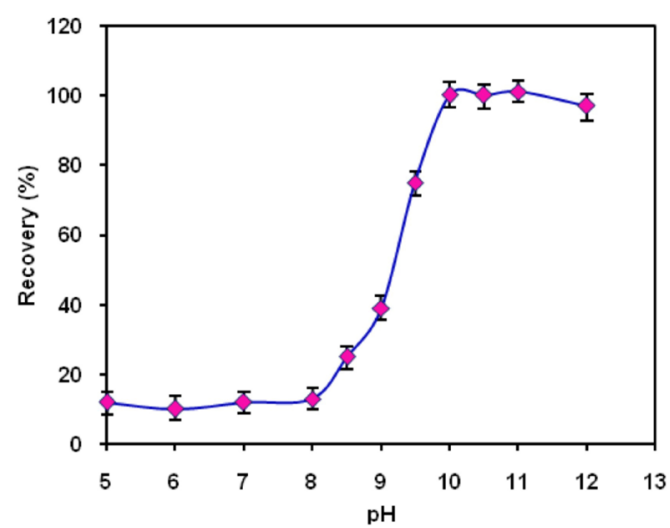

Figure 1. Effect of $\mathrm{pH}$ on the extraction efficiency of nickel. Utilized conditions: $\mathrm{Ni}^{2+}$ concentration: $50 \mu \mathrm{g} \mathrm{L}^{-1}$; PONPE $7.50 .10 \%$ (v/v); equilibrium temperature: room temperature; centrifugation time: $10 \mathrm{~min}$; sample volume: $50 \mathrm{~mL}$.

\section{Effect of buffer concentration}

Several buffer agents such as phosphate, carbonate, ammonium chloride/ammonia, glycine, boric acid/sodium hydroxide, triethanol amine and borax were tested for $\mathrm{pH}$ adjustment. In the presence of the latter five buffers no considerable signals were obtained. The suitable absorbance signal can be achieved using both the phosphate and carbonate buffers but the latter gives the highest signal. Therefore, carbonate buffer solution was chosen for the $\mathrm{pH}$ adjusting. The influence of carbonate buffer concentration in the range of $1 \times 10^{-5}$ to $8 \times 10^{-3} \mathrm{~mol} \mathrm{~L}^{-1}$ was investigated while the other experimental variables remained constant. As can be seen in Figure 2, the best performance was obtained in concentration range $1 \times 10^{-3}-8 \times 10^{-3} \mathrm{~mol} \mathrm{~L}^{-1}$. Therefore, $5 \times 10^{-3} \mathrm{~mol} \mathrm{~L}^{-1}$ buffer concentration was employed for further experiments.

\section{Effect of surfactant concentration}

The amount of PONPE 7.5 as an extracting agent is critical because it affects the quantitative extraction of analyte and therefore the method sensitivity. On the other hand, in the present work, PONPE 7.5 plays another role (as a chelating agent). Therefore, the study of the surfactant concentration would be important. Thus, the influence of PONPE 7.5 concentration on the extraction efficiency was studied in the range of $0.03-0.6 \%(\mathrm{v} / \mathrm{v})$. Figure 3 shows that PONPE 7.5 quantitatively extracts the $\mathrm{Ni}^{2+}$ ions from aqueous sample in the concentration range of $0.08-0.2 \%(\mathrm{v} / \mathrm{v})$, using a single step extraction procedure. The analytical signal was deteriorate at concentrations higher than $0.2 \%(\mathrm{v} / \mathrm{v})$ PONPE 7.5 due to the increase in the final volume of the surfactant that was caused the enrichment factor to decrease. Therefore, an amount of

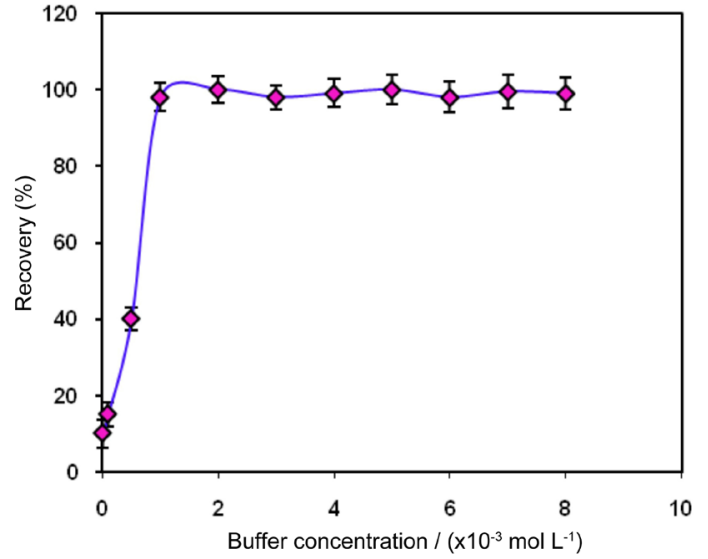

Figure 2. Effect of buffer concentration on the extraction efficiency of nickel. Utilized conditions: $\mathrm{Ni}^{2+}$ concentration: $50 \mu \mathrm{g} \mathrm{L}{ }^{-1}$; carbonate buffer ( $\mathrm{pH}$ 10); PONPE 7.5, 0.10\% (v/v); equilibrium temperature: room temperature; centrifugation time: $10 \mathrm{~min}$; sample volume: $50 \mathrm{~mL}$.

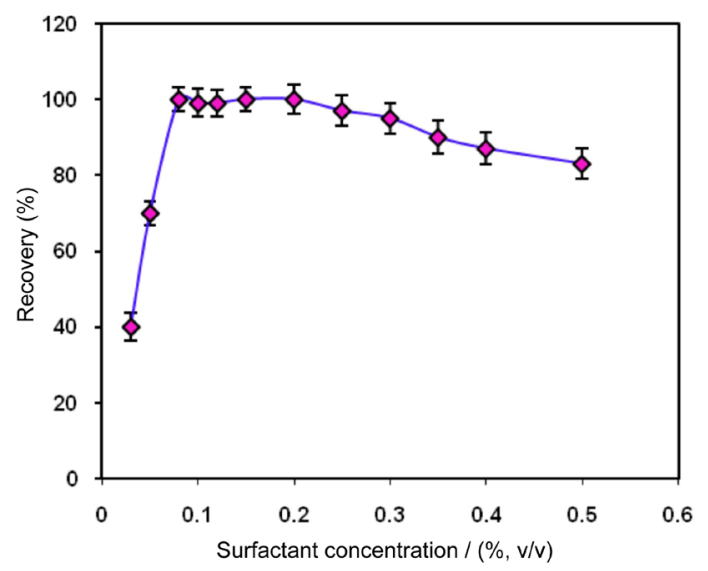

Figure 3. Effect of surfactant concentration on the extraction efficiency of nickel. Utilized conditions: $\mathrm{Ni}^{2+}$ concentration: $50 \mu \mathrm{g} \mathrm{L}{ }^{-1}$; carbonate buffer ( $\mathrm{pH}$ 10) concentration, $5 \times 10^{-3} \mathrm{~mol} \mathrm{~L}^{-1}$; equilibrium temperature: room temperature; centrifugation time: $10 \mathrm{~min}$; sample volume: $50 \mathrm{~mL}$.

$0.12 \%$ (v/v) PONPE 7.5 was chosen in order to achieve the greatest analytical signal and thereby the highest extraction efficiency.

Selection of the dilution agent for the surfactant-rich phase

The very high viscosity of the surfactant-rich phase is markedly decreased with a small amount of an appropriate diluting agent. Different solvents such as methanol, ethanol, acetone, tetrahydrofuran, and acidic solutions of methanol and ethanol were tried as diluting agents to select the one producing the optimal analytical signal. As can be seen in Figure 4, the best result was obtained for acidic methanol. In that way, methanol containing $0.1 \mathrm{~mol} \mathrm{~L}^{-1}$ nitric acid was added to the surfactant-rich phase after the separation of phases in order to facilitate its introduction into the nebulizer of the spectrometer. 


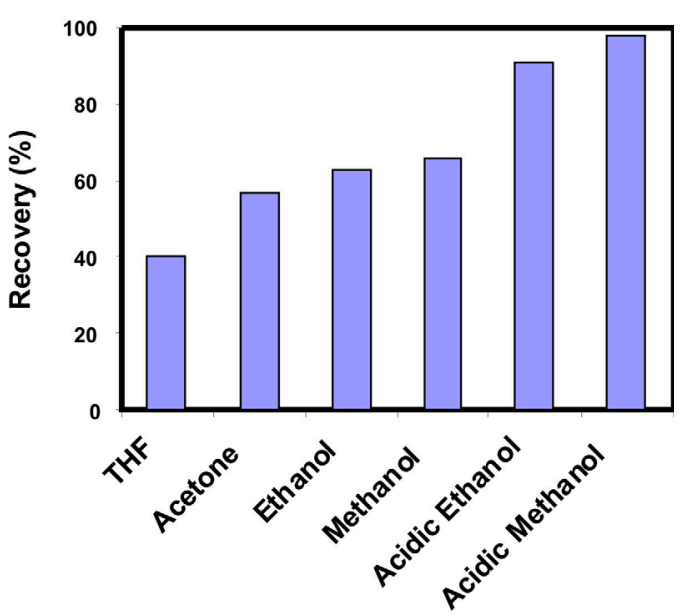

Figure 4. Effect of type of dilution agent, used to decrease the viscosity of surfactant-rich phase, on the extraction efficiency of nickel. Utilized conditions same as in Figure 3.

\section{Effect of ionic strength and centrifugation time}

The cloud point of micellar solutions can be controlled by addition of salts, alcohols, non-ionic surfactants and some organic compounds (salting-out effects). To date, most of the studies conducted have shown that ionic strength has no appreciable effect on the extraction efficiency. ${ }^{33}$ Therefore, to investigate the influence of ionic strength on extraction efficiency, various experiments were performed by adding different amounts of $\mathrm{NaNO}_{3}\left(0-1 \mathrm{~mol} \mathrm{~L}^{-1}\right)$ and the rest of the experimental conditions were kept constant. Based on the obtained results, the addition of $\mathrm{NaNO}_{3}$ within the interval of $0-0.2 \mathrm{~mol} \mathrm{~L}^{-1}$ had no significant effect on the CPE efficiency. The analytical signal decreased considerably by increasing $\mathrm{NaNO}_{3}$ concentrations $\left(0.2-1 \mathrm{~mol} \mathrm{~L}^{-1}\right)$. This effect might be explained by the additional surface charge when the $\mathrm{NaNO}_{3}$ concentration is very high, thus changing the molecular architecture of the surfactant and consequently the micelle formation process. ${ }^{50}$

The effect of centrifugation time upon analytical signal was also studied for the range of 5-20 min. A centrifugation time of $10 \mathrm{~min}$ at $4000 \mathrm{rpm}$ was selected for the entire procedure, since no appreciable improvements were observed for longer times.

\section{Effects of equilibrium temperature and time}

The cloud point temperature of the system under study is near room temperature. Therefore, the effect of the equilibrium temperature was investigated from room temperature to $50{ }^{\circ} \mathrm{C}$. It was found that the increase of temperature has no considerable effect upon the extraction efficiency and analytical signal. Thus, room temperature was used as an equilibrium temperature in CPE process.
An important point, with regard to incubation time, is that, for metals, their reaction with chelating agents and their transportation inside the micelle are kinetically controlled. Since in the proposed method no chelating agent was used, it seems that there's no need to incubation time. To study this, the influence of incubation time on CPE was investigated within a range from immediately after the preparation to $20 \mathrm{~min}$. It was observed that, in this system, the incubation time before centrifugation has no significant effect upon the extraction efficiency. So, in order to keep analysis time as short as possible the turbid solution was centrifuged immediately after the preparation at room temperature.

\section{Sample volume}

The nickel concentration in real samples such as natural waters is usually very low. Thus, the sample volume is one of the most important parameters in development of preconcentration method, since it determines the sensitivity enhancement of the technique. Thus, the effect of sample volume was examined in a range of $10-65 \mathrm{~mL}$ for $50 \mu \mathrm{g} \mathrm{L}{ }^{-1} \mathrm{Ni}$ under optimum conditions. It was observed that extraction efficiency of nickel was quantitative between $10-50 \mathrm{~mL}$ and for the higher sample volumes, extraction efficiency decreased. Subsequently, a sample volume of $50 \mathrm{~mL}$ was selected for further experiments.

\section{Interferences}

The effects of foreign species on the determination of nickel were investigated by measuring the absorbance of the solutions containing $50 \mu \mathrm{g} \mathrm{L}-1$ of this ion in the presence of various amounts of other ions. The tolerance limit was taken as the amount of added ion causing less or more than $5 \%$ relative error in the determination of nickel. Table 2 summarizes the maximum tolerances of the investigated cations and anions. As shown later, these results allow the interference-free determination of nickel in some water samples.

\section{Analytical figures of merit}

In the optimum conditions ( $\mathrm{pH} 10$; PONPE 7.5 concentration, $0.12 \%(\mathrm{v} / \mathrm{v})$; carbonate buffer concentration, $5 \times 10^{-3} \mathrm{~mol} \mathrm{~L}^{-1}$ and centrifugation time and speed, $10 \mathrm{~min}$ at $4000 \mathrm{rpm}$ ), a calibration graph was obtained by preconcentrating a series of 12 solutions according to procedure under experimental. Table 3 shows the analytical characteristics of the method. The calibration graph was linear up to $100 \mu \mathrm{g} \mathrm{L}^{-1}$, with a correlation coefficient $\mathrm{r}=0.9941$. The regression equation was $\mathrm{A}=0.008 \mathrm{C}_{(\mathrm{Ni})}+$ 
Table 2. Tolerance limits of interfering ions in the determination of $50 \mu \mathrm{g} \mathrm{L}{ }^{-1}$ of nickel

\begin{tabular}{lc}
\hline Coexisting ions & Interferent $/ \mathrm{Ni}^{2+}$ ratio \\
\hline $\mathrm{Li}^{+}, \mathrm{Na}^{+}, \mathrm{K}^{+}, \mathrm{Cs}^{+}, \mathrm{F}^{-}, \mathrm{Cl}^{-}, \mathrm{Br}^{-}, \mathrm{I}^{-}$, & \\
$\mathrm{SO}_{4}^{2-}, \mathrm{NO}_{3}^{-}, \mathrm{CO}_{3}^{2-}, \mathrm{CH}_{3} \mathrm{COO}^{-} \mathrm{Mg}^{2+}$, & $1000: 1$ \\
$\mathrm{Ca}^{2+}, \mathrm{Ba}^{2+}, \mathrm{Cr}(\mathrm{VI})$ & \\
$\mathrm{Cu}^{2+}, \mathrm{Cr}^{3+}$ & $800: 1$ \\
$\mathrm{Sr}^{2+}, \mathrm{Zn}^{2+}, \mathrm{Sn}^{2+}$ & $500: 1$ \\
$\mathrm{~V}(\mathrm{~V}), \mathrm{Bi}^{3+}, \mathrm{Al}^{3+}, \mathrm{Fe}^{3+}$ & $200: 1$ \\
$\mathrm{Ag}^{+}, \mathrm{Co}^{2+}, \mathrm{Pb}^{2+}, \mathrm{Cd}^{2+}$ & $100: 1$ \\
\hline
\end{tabular}

0.0063, where $\mathrm{A}$ is the absorbance and $\mathrm{C}_{(\mathrm{Ni})}$ is nickel concentration in $\mu \mathrm{g} \mathrm{L}^{-1}$. The limit of detection (LOD) and limit of quantification (LOQ), defined as $3 \mathrm{~S}_{\mathrm{b}} / \mathrm{m}$, and $10 \mathrm{~S}_{\mathrm{b}} / \mathrm{m}$ (where $\mathrm{S}_{\mathrm{b}}$ is the standard deviation of the blank and $\mathrm{m}$ is the slope of the calibration curve) were $0.5 \mu \mathrm{g} \mathrm{L}-1$ and $1.6 \mu \mathrm{g} \mathrm{L}{ }^{-1}$, respectively. The relative standard deviation (RSD) resulting from the analysis of 6 replicates of $50 \mathrm{~mL}$ solution containing 50 and $80 \mu \mathrm{g} \mathrm{L}^{-1}$ of nickel were $2.67 \%$ and $1.97 \%$, respectively. The enrichment factor, defined as the ratio of the final concentration of the nickel in the surfactant rich-phase and its concentration in the original sample solution, was 100 .

Table 3. Analytical characteristics of the proposed method

\begin{tabular}{lcc}
\hline $\begin{array}{l}\text { Analytical } \\
\text { parameters }\end{array}$ & $\begin{array}{c}\text { Without } \\
\text { preconcentration }\end{array}$ & $\begin{array}{c}\text { With } \\
\text { preconcentration }\end{array}$ \\
\hline Linear range $\left(\mu \mathrm{g} \mathrm{L}{ }^{-1}\right)$ & $100-10000$ & $2-100$ \\
Intercept & 0.0117 & 0.0063 \\
Slope & $8.0 \times 10^{-5}$ & $8.0 \times 10^{-3}$ \\
LOD $\left.(\mu \mathrm{g} \mathrm{L})^{-1}\right)^{\mathrm{a}}$ & 36.2 & 0.5 \\
Correlation coefficient & 0.9950 & 0.9941 \\
RSD $(\%, \mathrm{n}=6)^{\mathrm{b}}$ & $1.95(5000)$ & $2.67(50)$ \\
& & $1.97(80)$ \\
Enrichment factor & & 100 \\
\hline
\end{tabular}

${ }^{\mathrm{a}} \mathrm{Calculated}$ as the amount of nickel required to yields a net peak equal to three times the standard deviation of the background signal $(3 \mathrm{~s}) ;{ }^{\text {b Values in }}$ parentheses are the nickel concentration $\left(\mu \mathrm{g} \mathrm{L}^{-1}\right)$ for which the RSD was obtained; ${ }^{\mathrm{c}} \mathrm{Calculated}$ as the ratio of the final concentration of the nickel in the surfactant rich-phase and its concentration in the original sample solution.

\section{Application of the method}

To test the reliability of the method, it was applied for the determination of $\mathrm{Ni}^{2+}$ ions in six water samples including tap water, rain water, mineral water, spring water, river water and waste water. In order to verify the accuracy of the established procedure, recovery experiments were also carried out by spiking the samples with different amounts of nickel before any pretreatment. Table 4 shows the obtained results. As can be seen, recoveries between 97.4 and $101.0 \%$ were obtained, which confirm the accuracy of the proposed method. Additionally, the accuracy of the proposed procedure was verified by applying the method to the determination of nickel in a standard reference material, NIST SRM 1643e (trace elements in water), with certified $\mathrm{Ni}^{2+}$ content of $62.41 \pm 0.69 \mu \mathrm{g} \mathrm{L}^{-1}$. The obtained value for nickel by using the proposed procedure was $61.82 \pm 0.94 \mu \mathrm{g} \mathrm{L}^{-1}$ (mean of three determinations \pm standard deviation), which at $95 \%$ confidence level, is in good agreement with the certified concentration. It can be concluded that the proposed procedure is reliable for the determination of nickel in water samples.

Table 4. Determination of nickel in water samples (results of recoveries of spiked samples)

\begin{tabular}{|c|c|c|c|}
\hline Samples & $\begin{array}{c}\text { Added } \mathrm{Ni}^{2+} \\
\left(\mu \mathrm{g} \mathrm{L}^{-1}\right)\end{array}$ & $\begin{array}{l}\text { Found } \mathrm{Ni}^{2+} \\
\left.(\mu \mathrm{g} \mathrm{L})^{-1}\right)^{\mathrm{a}}\end{array}$ & $\begin{array}{c}\text { Recovery } \\
(\%)^{\mathrm{b}}\end{array}$ \\
\hline \multirow[t]{3}{*}{ Tap water ${ }^{\mathrm{c}}$} & - & not detected & - \\
\hline & 20.0 & $19.7 \pm 0.3$ & 98.5 \\
\hline & 50.0 & $50.5 \pm 0.4$ & 101.0 \\
\hline \multirow[t]{3}{*}{ Rain water ${ }^{\mathrm{d}}$} & - & not detected & - \\
\hline & 20.0 & $19.5 \pm 0.2$ & 97.5 \\
\hline & 50.0 & $49.3 \pm 0.1$ & 98.6 \\
\hline \multirow[t]{3}{*}{ Mineral water } & - & not detected & - \\
\hline & 20.0 & $19.7 \pm 0.3$ & 98.5 \\
\hline & 50.0 & $48.9 \pm 0.2$ & 97.8 \\
\hline \multirow[t]{3}{*}{ Spring water ${ }^{\mathrm{f}}$} & - & $6.7 \pm 0.2$ & - \\
\hline & 20.0 & $26.6 \pm 0.2$ & 99.5 \\
\hline & 50.0 & $55.4 \pm 0.3$ & 97.4 \\
\hline \multirow[t]{3}{*}{ River water ${ }^{\mathrm{g}}$} & - & $11.8 \pm 0.5$ & - \\
\hline & 20.0 & $31.6 \pm 0.2$ & 99.0 \\
\hline & 50.0 & $61.5 \pm 0.3$ & 99.4 \\
\hline \multirow[t]{3}{*}{ Waste water ${ }^{\mathrm{h}}$} & - & $38.6 \pm 0.2$ & - \\
\hline & 20.0 & $58.7 \pm 0.2$ & 100.5 \\
\hline & 50.0 & $88.5 \pm 0.4$ & 99.8 \\
\hline
\end{tabular}

${ }^{\mathrm{a}}$ Mean of three experiments \pm standard deviation; ${ }^{\mathrm{b}}$ Recovery $(\%)=$ [(found-base)/added] $\times 100$; ' from drinking water system of Tabriz, Iran; ${ }^{\mathrm{d}}$ collected at Tabriz City, Iran (March 2010); ' obtained from Vata Co.,

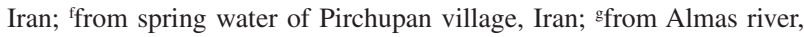
East Azarbaijan, Iran; hrom waste water of plating factory, Tabriz, Iran.

Comparison of the proposed procedure with other CPE procedures

We compared in Table 5 the limit of detection (LOD), enhancement or enrichment factor, and the sample volume in the proposed technique and by some other recent literature CPE techniques for the extraction and determination of nickel in real samples. As could be seen, the proposed method has low LOD and good enrichment factor. The method developed in this work is proposed as a suitable alternative to more expensive instruments for nickel determination at trace levels. Simple operation procedure makes the sample preparation very easy and rapid, only a few minutes are needed before instrumental 
Table 5. Comparison of characteristic performance data obtained using the proposed procedure with the some recent published CPE methods for preconcentration of nickel prior to FAAS determination

\begin{tabular}{|c|c|c|c|c|c|}
\hline Chelating agent & Surfactant & $\begin{array}{c}\text { Sample } \\
\text { volume }(\mathrm{mL})\end{array}$ & $\mathrm{EF}^{\mathrm{a}}$ & $\begin{array}{l}\text { LOD } \\
\left(\mu \mathrm{g} \mathrm{L}^{-1}\right)\end{array}$ & Reference \\
\hline Magneson I ${ }^{\mathrm{b}}$ & Triton X-114 & 25 & 17 & 2.7 & 51 \\
\hline TAN $^{\mathrm{c}}$ & Triton X-114 & 15 & 30 & 5 & 52 \\
\hline IYPMI $^{\mathrm{d}}$ & Triton X-114 & 15 & 39 & 2.1 & 36 \\
\hline $\mathrm{MPKO}^{\mathrm{e}}$ & Triton X-114 & 15 & 58 & 1.9 & 35 \\
\hline Me-BTABr ${ }^{f}$ & Triton X-114 & 10 & 23 & 1.1 & 34 \\
\hline Ligandless & Tween 80 & 10 & 10 & 1.1 & 43 \\
\hline Ligandless & PONPE 7.5 & 50 & 100 & 0.5 & Present work \\
\hline
\end{tabular}

a Enhancement or enrichment factor; ${ }^{\mathrm{b}} p$-nitrophenylazoresorcinol; ${ }^{\mathrm{c}}$ 1,2-thiazolylazo-2-naphthol; ${ }^{\mathrm{d}}$ 3-[(indolin-3-yl)(phenyl)methyl]indoline; ${ }^{\mathrm{e}}$ methyl-2pyridylketone oxime; ${ }^{\mathrm{f}} 2$-[2'-(6-methyl-benzothiazolylazo)]-4-bromophenol.

analysis. Thus, the proposed method could be of great interest especially for nickel determination in routine analytical laboratories.

\section{Conclusions}

This paper proposes a new method for the preconcentration and determination of trace amounts of nickel by ligandless CPE combined with FAAS. The proposed procedure does not need any chelating agent, heating, long incubation time and cooling after centrifugation. Phase separation can be achieved at room temperature and the extraction efficiency is high, resulting in low detection limits and high preconcentration factors. The preconcentration of $50 \mathrm{~mL}$ of samples in the presence of PONPE 7.5 gives a preconcentration factor of 100 . Therefore, the proposed CPE technique can effectively improve the sensitivity of FAAS. The results of this study clearly show the potential and versatility of this method, which could be applied to nickel monitoring in various water samples.

\section{Acknowledgments}

The financial support from the Research Council of Azarbaijan University of Tarbiat Moallem (AUTM, Iran) is gratefully acknowledged.

\section{References}

1. Aouarram, A.; Galindo-Riaño, M. D.; García-Vargas, M.; Stitou, M.; El Yousfi, F.; Talanta 2007, 71, 165.
2. Dadfarnia, S.; Haji Shabani, A. M.; Shirani Bidabadi, M.; Jafari, A. A.; J. Hazard. Mater. 2010, 173, 534.

3. http://www.who.int/water_sanitation_health/dwq/gdwq3_8.pdf, accessed in October 2010.

4. Alieva, R. A.; Melikova, V. I.; Chyragov, F. M.; J. Anal. Chem. 2007, 62, 526.

5. Mohanapriya, S.; Lakshminarayanan, V.; Talanta 2007, $71,493$.

6. Talio, M. C.; Luconi, M. O.; Masi, A. N.; Fernández, L. P.; J. Pharm. Biomed. Anal. 2010, 52, 694.

7. Zhang, C.; Li, Y.; Wu, P.; Yan, X. P.; Anal. Chim. Acta 2009, 652, 143.

8. Liu, L.; Deng, H.; Wu, L.; Zheng, C.; Hou, X.; Talanta 2010, 80, 1239.

9. Gondal, M.A.; Hussain, T.; Talanta 2007, 71, 73.

10. Karabulut, A.; Aslan, I.; Dumlupınar, R.; Tirasoglu, E.; Budak, G.; J. Quant. Spectrosc. Radiat. Transfer 2005, 94, 373.

11. Pourreza, N.; Zolgharnein, J.; Kiasat, A. R.; Dastyar, T.; Talanta 2010, 81, 773 .

12. Bezerra, M. A.; Conceição, A. L. B.; Ferreira, S. L. C.; Anal. Bioanal. Chem. 2004, 378, 798.

13. Yebra, M. C.; Cancela, S.; Cespón, R. M.; Food Chem. 2008, 108, 774 .

14. Liu, J.; Jang, G.; Meng, Z.; Qiao, B.; J. Am. Oil. Chem. Soc. 2009, 86, 967.

15. Olmeda, P.; Pla, A.; Hernández, A. F.; López-Guardino, O.; Gil, L. R. F.; Anal. Chim. Acta 2010, 659, 60.

16. Botelho, G. M. A.; Campos, R. C.; Jackson, K. W.; Mikrochim. Acta 2001, 136, 43.

17. Ilander, A.; Väisänen, A.; Anal. Chim. Acta 2007, 602, 195.

18. Moss, J. C.; Hardaway, C. J.; Richert, J. C.; Sneddon, J.; Microchem. J. 2010, 95, 5. 
19. Otero-Romaní, J.; Moreda-Piñeiro, A.; Bermejo-Barrera, P.; Martin-Esteban, A.; Microchem. J. 2009, 93, 225.

20. Muñoz, E.; Palmero, S.; García- García, M. A.; Talanta 2002 , 57,985 .

21. Rojas, F. S.; Ojeda, C. B.; Pavõn, J. M. C.; Microchem. J. 2010, $94,7$.

22. Moneeb, M.S.; Talanta 2006, 70, 1035.

23. Singh, A. K.; Singh, P.; Mehtab, S.; J. Inclusion Phenom. Macrocyclic Chem. 2009, 63, 87.

24. Kapturski, P.; Bobrowski, A.; J. Electroanal. Chem. 2008, 617, 1.

25. Ghaedi, M.; Spectrochim. Acta, Part A 2007, 66, 295.

26. Reddy B. R.; Priya, D. N.; J. Power Sources 2006, 161, 1428.

27. Haji Shabani, A. M.; Dadfarnia, S.; Shahbazi, Z.; Jafari, A. A.; Bull. Chem. Soc. Ethiop. 2008, 22, 323.

28. Arain, M. B.; Kazi, T. G.; Jamali, M. K.; Afridi, H. I.; Jalbani, N.; Sarfraz, R. A.; Baig, J. A.; Memon, M. A.; J. Hazard. Mater. 2008, 160, 235.

29. Khorrami, A. R.; Naeimi, H.; Fakhari, A. R.; Talanta 2004, 64 , 13.

30. Ferreira, S. L. C.; dos Santos, W. N. L.; Lemos, V. A.; Anal. Chim. Acta 2001, 445, 145.

31. Narin, I.; Soylak, M.; Anal. Chim. Acta 2003, 493, 205.

32. Tuzen, M.; Soylak, M.; Citak, D.; Ferreira, H. S.; Korn, M. G. A.; Bezerra, M. A.; J. Hazard. Mater. 2009, 162, 1041.

33. Safavi, A.; Abdollahi, H.; Hormozi Nezhad, M. R.; Spectrochim. Acta, Part A 2004, 60, 2897.

34. Lemos, V. A.; Franca, R. S.; Moreira, B. O.; Sep. Purif. Technol. 2007, 54, 349.

35. Ghaedi, M.; Shokrollahi, A.; Ahmadi, F.; Rajabi, H. R.; Soylak, M.; J. Hazard. Mater. 2008, 150, 533.

36. Ghaedi, M.; Shokrollahi, A.; Niknam, K.; Niknam, E.; Soylak, M.; Cent. Eur. J. Chem. 2009, 7, 148.
37. Shirani Bidabadi, M.; Dadfarnia, S.; Haji Shabani, A. M.; J. Hazard. Mater. 2009, 166, 291.

38. Jiang, H.; Qin, Y.; Hu, B.; Talanta 2008, 74, 1160.

39. Yoshikuni, N.; Baba, T.; Tsunoda, N.; Oguma, K.; Talanta 2005 , $66,40$.

40. Lemos, V. A.; David, G. T.; Microchem. J. 2010, 94, 42.

41. Bezerra, M. de. A.; Conceição, L. B. A.; Ferreira, S. L. C.; Microchim. Acta 2006, 154, 149.

42. Silva, M. F.; Cerutti, E. S.; Martinez, L. D.; Microchim. Acta 2006, 155, 349.

43. Candir, S.; Narin, I.; Soylak, M.; Talanta 2008, 77, 289.

44. Manzoori, J. L.; Abdolmohammad-Zadeh, H.; Amjadi, M.; Talanta 2007, 71, 582.

45. Watanabe, H.; Tanaka, H.; Talanta 1978, 25, 585.

46. Sombra, L. L.; Luconi, M. O.; Fernández, L. P.; Olsina, R. A.; Silva M. F.; Martínez, L. D.; J. Pharm. Biomed. Anal. 2003, 30, 1451

47. Manzoori, J. L.; Abdolmohammad-Zadeh, H.; Amjadi, M.; J. Hazard. Mater. 2007, 144, 458.

48. Manzoori, J. L.; Abdolmohammad-Zadeh, H.; Amjadi, M.; Microchim. Acta 2007, 159, 71.

49. Lurie, J.; Handbook of Analytical Chemistry, English Translation, Mir Publisher: Moscow, 1975.

50. Ghaedi, M.; Shokrollahi, A.; Niknam, K.; Niknam, E.; Najibi, A.; Soylak, M.; J. Hazard. Mater. 2009, 168, 1022.

51. Sahin, Ç. A.; Efeçınar, M.; Satiroglu, N.; J. Hazard. Mater. 2010, 176, 672 .

52. Silva, S. G.; Oliveira, P. V.; Nóbrega, J. A.; Rocha, F. R. P.; Anal. Methods 2009, 1, 68.

Submitted: August 12, 2010 Published online: November 4, 2010 